Krzysztof Grabowski

\title{
Bezpieczeństwo czlowieka i państwa edukacyjnym wyzwaniem początku XXI wieku
}

\section{Streszczenie}

Celem artykułu jest próba zapoznania czytelnika ze współczesnymi wyzwaniami stawianymi przed edukacją, mającymi kluczowe znaczenie dla wzrostu bezpieczeństwa człowieka, państwa, a w konsekwencji świata. Pierwsza część opracowania stanowi wprowadzenie w główne obszary poruszanych tematów. W pewnym stopniu część ta jest także częścią teoretyczną. Głównym jej zadaniem jest możliwie właściwe wyjaśnienie kluczowych kategorii pojawiających się w tym artykule, a także przedstawienie i wyjaśnienie celów, do jakich powinna zmierzać i jakimi powinna się kierować edukacja, przed którą stawia się dzisiaj niełatwe zadanie wyksztalcenia człowieka gotowego sprostać współczesnym wyzwaniom związanym z postępującą globalizacją w dziedzinach myśli, techniki, kultury i sztuki. Przeważająca część artykułu poświęcona jest zagrożeniom związanym z rozwojem nowych kategorii terroryzmu, transnarodowej przestępczości oraz pojawiającym się nowym formom ideologii i fundamentalizmów religijnych zagrażających stabilności dzisiejszej cywilizacji. Opracowanie porusza także przez niektórych bagatelizowane, jednakże nie mniej istotne problemy stanowiące wyzwania i niosące zagrożenia będące skutkiem dynamicznic rozwijającej się cywilizacji. Do grupy tej należy zaliczyć zagrożenia: ekonomiczne, ekologiczne, społeczne, a także zagrożenia kulturowe niesione kolejną falą cywilizacyjną.

Słowa kluczowe: bezpieczeństwo, polityka, edukacja 


\title{
Human and National Security as an Educational Challenge at the Beginning of the 21st Century
}

\begin{abstract}
The article attempts to familiarise the reader with modern challenges placed in front of education, which have key meaning for the rise of safety of the people, the nation and, as a consequence, the world. First part of the case study accounts for an introduction into the main areas of the broached subjects. In a way this part is also a theoretical part. Its main task is to explain, in a most adequate manner, the key categories to appear in this article, as well as to present and explain the goals placed in front of education. At the same time, education faces a difficult task, in form of educating a man ready to achieve modern challenges linked with ongoing globalization in fields of thought, technology, culture and art. The prevalent part of the article is devoted to dangers related to development of new categories of terrorism, transnational crime and emerging new forms of ideologies and religious fundamentalisms which endanger present-day civilization's stability. This case study also tackles economical and social problems, as well as cultural dangers brought in with the next civilization wave. The author attempts, in an uncomplicated manner, to explain the essence of correct identification of the challenges and efficient elimination of emerging dangers.
\end{abstract}

Keywords: security, politics, education

Większości z nas współczesność kojarzy się z wysoce dynamicznym postępem technicznym dotyczącym wszystkich dziedzin życia. Z całą pewnością czas ten utożsamiać należy z postępującym procesem globalizacji w dziedzinie myśli, kultury oraz szeroko rozumianej nauki. Jednym z immanentnych wyznaczników tej prekluzji jest postępująca integracja państw, której szczególny wyraz obserwować możemy w obszarze europejskim, a także w próbie utworzenia wspólnego euroatlantyckiego obszaru gospodarczego. Procesowi temu towarzyszy stałe przełamywanie barier stanowiących przeszkody dla ciągłości postępu określonego przez Alvina Tof- 
flera mianem kolejnej „fali”" Należy jednak pamiętać, że zapoczątkowany w latach 60 . XX wieku postmodernizm, określany również epoką postindustrialną lub ponowoczesnością, której wytworem jest zmakdonaldyzowne społeczeństwo płynnej nowoczesności niosące ze sobą poza postępem szereg wyzwań i zagrożeń, poprzedzony był czasem konfliktów mierzonych w globalnej skali. Przyczyną antagonizmów w przeważającej mierze okazały się zgubne dla świata idee totalitaryzmów. Poprzedziła je pierwsza wojna światowa, za wybuch której, zdaniem Henry'ego Kissingera, odpowiedzialnością obarczyć można lekkomyślność ówczesnych przywódców, którzy dążąc do dwubiegunowego podziału świata, wyprzedzili „schemat zimnej wojny o pięćdziesiąt lat". Na wzmiankę w tym miejscu zasługuje osoba cesarza Wilhelma II, a w szczególności nieudolna próba prowadzenia polityki o charakterze globalnym przez ówczesne Cesarstwo Niemieckie, która zaprowadziła świat nad skraj przepaści ${ }^{2}$ Należy w tym miejscu poczynić uwagę, że mimo doświadczenia wynikającego z lat poprzednich świat nie uwolnił się od graczy politycznych zmierzających do odbudowy imperium i uzyskania statusu hegemona. Na naszych oczach rozgrywa się potyczka o nowy podział świata i wprowadzenie „,nowego-starego" ładu, tak dobrze zobrazowanego przez literaturę ostatnich pokoleń.

Wraz z postępującą ponowoczesnością można zaobserwować narodziny epoki nanotechnologii, która stała się motorem dla wielu dziedzin współczesnej nauki. Przyśpieszeniu uległ rozwój technologii związanych z informatyką, medycyną, komunikacją, obronnością itp. W procesie tym obserwowalny jest wynikający z niego stały wzrost liczby zagrożeń (negatywnych wartości) ${ }^{3}$ dla bezpieczeństwa człowieka oraz państwa. Poszerzając perspektywę znaczeniową tego obszaru, przez zagrożenia należy rozumieć „zespoły czynników negatywnie oddziałujących na byt i rozwój”4 oraz trwanie podmiotu. Są one bezpośrednim następstwem wyzwań i szans, którym nie sprostało lub których nie podjęło społeczeństwo i państwo. Niebezpieczeństwa te mogą wpływać w sposób destrukcyjny pośrednio lub bezpośrednio na strukturę społeczną i podmiot. Zagrożenia te można podzielić na: ,potencjalne i realne; subiektywne i obiektywne; zewnętrzne

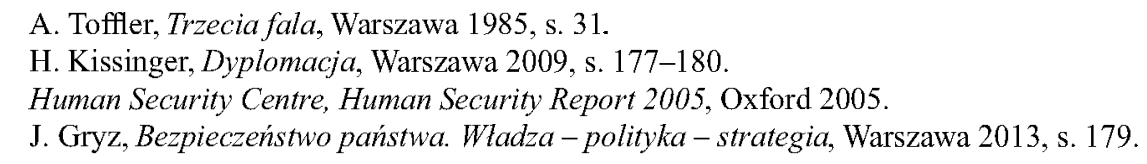


i wewnętrzne; militarne i pozamilitarne; kryzysowe i wojenne oraz intencjonalne i przypadkowe"s.

Do grupy najczęśsiej wymienianych niewątpliwie należą zagrożenia militarne i związana z nim proliferacja broni masowego rażenia ${ }^{6}$. W dalszym ciągu zagrożeniem dla bezpieczeństwa człowieka i cywilizacji są odradzające się nacjonalizmy towarzyszące procesom narodowo- i państwotwórczym? $^{7}$. Do rangi zagrożenia w ostatnim czasie urósł brak poszanowania suwerenności i integralności niepodległych państw. Powyższą listę poszerzają: terroryzm, piractwo oraz zorganizowana przestępczość transnarodowa ${ }^{8}$. Efektem pogłębiającej się globalizacji w dziedzinie informatyki są zagrożenia cybernetyczne ${ }^{9}$. Równie często wymieniane są zagrożenia związane ze sferą ekonomiczną, kulturową, ekologiczną, a także demograficzną społeczeństwa oraz państwa ${ }^{10}$. Na szczególną uwagę zasługują przenoszone wraz z procesem uniwersalizacji zagrożenia dla wartości autotelicznych wyznaczających prawa i wolności człowieka ${ }^{11}$. Wszystkie wymienione należą do grupy zagrożeń cywilizacyjnych niesionych wraz z tofflerowską ,trzecią falą". Powyższy katalog nie stanowi zbioru zamkniętego i z całą pewnością można by uzupełnić go o szereg innych kategorii.

Większość z wymienionych powyżej niebezpieczeństw należy do grupy zagrożeń niesymetrycznych określanych też niemilitarnymi. Stanowiły one poważne wyzwanie $\mathrm{i} w$ dalszym ciągu są nim $\mathrm{w}$ procesie edukacji dla bezpieczeństwa. Wyzwanie w powyższym kontekście należy rozumieć jako zespół sytuacji trudnych oraz „,zjawisk negatywnic ocenianych”, które w wyniku złej percepcji badaczy, polityków, jednostek i społeczeństwa

S. Koziej, Bezpieczeństwo: istota, podstawowe kategorie i historyczna ewolucja, Bezpieczeństwo Narodowe 2011, t. 18, nr 2, s. 29.

6 M. Kaczmarski, Problematyka zbrojeń i rozbrojenia, [w:] Bezpieczeństwo międzynarodowe po zimnej wojnie, (red.) R. Zięba, Warszawa 2008, s. 520-545.

R. Zięba, Nowe wyzwania i zagrożenia dla bezpieczeństwa międzynarodowego: aspekt metodologiczny, [w:] Świat wobec wspólczesnych wyzwań i zagrożeń, (red.) J. Symonides, Warszawa 2010, s. 344-346.

8 I. Wyciechowska, Przestępczość zorganizowana i przemyt ludzi, [w:] Świat wobec wspólczesnych wyzwań i zagrożen, (red.) J. Symonides, Warszawa 2010, s. 511-533.

9 M. Madej, Cyberterroryści, cyberprzestępcy i hakerzy, [w:] Świat wobec wspólczesnych wyzwań i zagrożeń, (red.) J. Symonides, Warszawa 2010, s. 390-406.

10 W. Kitler, Istota bezpieczeństwa narodowego, [w:] Edukacja obronna spoleczeństwa, (red.) B. Wiśniewski, W. Fehler, Bialystok 2006, s. 44-58.

11 S. Sulowski, O nowym paradygmacie bezpieczeństwa, [w:] Bezpieczeństwo wewnętrzne państwa: Wybrane zagadnienia, Warszawa 2009, s. 12. 
mogą się przerodzić w zagrożenia. Z. Pietras zwraca uwagę, że bezpieczeństwo, jako stan świadomości, jest „kategorią wylącznie subiektywną"12. Wynika z tego trudność w ocenie i rozróżnieniu zjawisk mających charakter wyzwań od tych o charakterze zagrożeń. Zakłócone postrzeganie najczęściej spowodowane jest: „złożonością środowiska”, obiegiem prawdziwych i fałszywych informacji, a także brakiem dostatecznego profesjonalizmu u obserwatorów ${ }^{13}$. Zdaniem M. Kozuba wyzwania „to nie tylko zjawiska i procesy nowe, ale również elementy zbioru prognozowanych zdarzeń, stanów, procesów, wymagające reakcji sformułowania odpowiedzi i podjęcia stosownych działań [...] lub [...] przeciwdziałania, gdy mają one charakter zagrożenia"14. Istotą właściwego rozpoznania jest racjonalna reakcja na prognozowane wyzwania. Umożliwia to wcześniejsze przygotowanie odpowiedniej strategii na podstawie analizy i oceny „zdiagnozowanych już zagrożeń" oraz wdrożenia koniecznych działań (skorzystanie z szans) umożliwiających zapobieganie wystąpieniu sytuacji niebezpiecznych ${ }^{15}$.

Istotnymi pojęciami, które należy wyjaśnić, podejmując się próby rozstrzygania o zagrożeniach i wyzwaniach edukacji dla narodu społeczeństwa i państwa, są przywołane powyżej pojawiające się szanse oraz ryzyko. Obie kategorie, jak wynika z wcześniejszych rozważań, trwale uczestniczą w procesie minimalizacji lub zupełnej eliminacji współcześnie pojawiających się niebezpieczeństw dla wspomnianych podmiotów i przedmiotów bezpieczeństwa. Szansę należy rozpatrywać jako proces, w którym pojawiają się czynniki o charakterze szybko przemijającym, pozytywnie wpływające na podmiot lub przedmiot. Stanowią one bezpośredni rezultat wyzwań i zagrożeń, które państwo może skutecznie przy ich wykorzystaniu wyeliminować. Ryzyko jest wynikiem obszaru niepewności (tzw. zmienne niezależne) dotyczy bezpośrednio aktywności i zaangażowania podmiotu na arenie wewnętrznej i międzynarodowej. „Ryzyko może [...] być rozpatrywane jako właściwość decyzji politycznej i jej implementacji, a także jako swoista miara stanu, zjawiska, procesu, trendu, megatrendu" dla bezpieczeństwa podmiotów, jakimi są naród, społeczeństwo i państwo ${ }^{16}$.

\footnotetext{
Z. J. Pietraś, Podstawy teorii stosunków międzynarodowych, Lublin 1986, s. 162.

R. Zięba, Nowe wyzwania..., s. 340.

M. Kozub, Myśleć strategicznie o bezpieczeństwie przyszlości, Warszawa 2013, s. 9-10. Ibidem, s. 9.

J. Gryz, op. cit., s. 180.
} 
Dla właściwego zrozumienia tego opracowania za stosowne uważam przedstawienie oraz wyjaśnienie zakresu obszaru znaczeniowego pojęcia „bezpieczeństwo".

Termin „bezpieczeństwo" wprost wywodzi się z łaciny (securitas). W bezpośrednim tłumaczeniu oznacza spokój, pewność trwania, stan niezagrożenia ${ }^{17}$. W wąskim rozumieniu bezpieczeństwo można rozumieć jako stan bez zagrożenia. Poszerzając perspektywę, należy zauważyć, że bezpieczeństwo wiąże się bezpośrednio z procesem zmierzającym do zaspokajania niezbędnych potrzeb wszystkich uczestników zarówno w wymiarze narodowym, jak też międzynarodowym. Można zatem podzielić je na trzy kategorie: podmiotowe, przedmiotowe i funkcjonalne ${ }^{18}$.

Bezpieczeństwo w rozumieniu podmiotowym zdaniem R. Zięby należy rozpatrywać jako „potrzebę podmiotową o charakterze egzystencjonalnym, wyrażającą dążenie do uzyskania pewności istnienia i przetrwania, posiadania oraz funkcjonowania i rozwoju" państwa ${ }^{19}$. Ujęcie to odnosi się nie tylko do podmiotów politycznych, lecz dotyczy całej społeczności międzynarodowej. Walor ten kojarzyć należy z możliwością stałego i niezakłóconego rozwoju oraz przetrwaniem, czyli z zagwarantowaniem status quo obywateli pojmowanych jako główny podmiot bytu politycznego. Tak więc właściwe zagwarantowanie bezpieczeństwa w powyższych wymiarach jest niezbędnym składnikiem interesu narodowego, który zabezpiecza oraz umożliwia wielopłaszczyznowy oraz niezagrożony rozwój społeczeństwa, a tym samym realizację żywotnego interesu narodu, społeczeństwa i państwa ${ }^{20}$.

Bezpieczeństwo przedmiotowe to środki i metody używane do modelowania przeświadczenia o stanie posiadania poszczególnych uczestników stosunków międzynarodowych. To także gwarancja zachowania tożsamości i zapewnienie swobody nieskrępowanego rozwoju we wszystkich płaszczyznach. Jest to bardzo pojemna kategoria i zawiera w zasadzie wszystkic najważniejsze wyznaczniki związane $z$ bezpieczeństwem społeczeństwa i państwa. Należy do niej zaliczyć:

17 R. Zięba, Teoria ogólna bezpieczeństwa w stosunkach międzynarodowych, [w:] Stosunki międzynarodowe w XXI wieku, (red.) E. IIaliżak, Warszawa 2006, s. 936.

18 Idem, Pojęcia i istota bezpieczeństwa międzynarodowego, [w:] Bezpieczeństwo międzynarodowe po zimnej wojnie, (red.) R. Zięba, Warszawa 2008, s. 16-22.

19 Idem, Nowe wyzwania..., s. 335.

20 J. Stańczyk, Wspótczesne pojmowanie bezpieczeństwa, Warszawa 1996, s 43. 
- bezpieczeństwo polityczne, które oznacza stabilny rząd kierujący się klarowną i długofalową polityką skuteczną dla państwa oraz czytelną dla środowiska międzynarodowego;

- bezpieczeństwo militarne to odpowiednio silna i właściwie wyszkolona armia zdolna do realizacji zadań związanych z zapewnieniem niepodległości, suwerenności politycznej oraz trwania państwa w długim okresie;

- bezpieczeństwo ekonomiczne związane jest z bogactwem w surowce naturalne niezbędne do zapewnienia potrzeb energetycznych, właściwie rozwinięta gospodarka zapewnia wszystkie środki niezbędne do realizacji potrzeb życiowych. $Z$ bezpieczeństwem ekonomicznym łączy się bezpieczeństwo socjalne i finansowe obywateli, którego jednym z głównych zadań jest wspieranie demografii i możliwości odnawialnych społeczeństwa. To także wysoki stopień edukacji umożliwiający dostęp do korzystania z najnowszych technologii;

- bezpieczeństwo kulturowe, trwale związane z edukacją, ma na celu zapewnienie nieskrępowanego dostępu wszystkim obywatelom do zdobyczy kultury materialnej i niematerialnej narodu, wpojenie szacunku do symboli narodowych oraz znajomość dziedzictwa narodowego;

- bezpieczeństwo humanitarne wyraża się w bezkompromisowości i zdolności niesienia natychmiastowej pomocy współobywatelom i innym narodom;

- bezpieczeństwo ekologiczne ma na celu pozostawienie środowiska naturalnego w stanie zapewniającym niczym niezakłócony rozwój kolejnym pokoleniom;

- bezpieczeństwo ideologiczne - polityka nigdy nie była i nie będzie wolna od wpływów ideologii. Jej obecność w znacznym stopniu służy stałemu rozwojowi, lecz należy pamiętać, że tylko właściwe pojmowanie potrzeb narodu i państwa oparte na ogólnym porozumieniu, czyli swoboda w wyrażaniu opinii oraz prezentowaniu przekonań gwarantuje wewnętrzną stabilność i bezpieczeństwo oraz trwały wzrost znaczenia bytu politycznego na arenie międzynarodowej ${ }^{21}$.

Umiejętność właściwego zabezpieczenia powyższych wartości o znaczeniu egzystencjalnym nie tylko podnosi poziom bezpieczeństwa jednostki i społeczeństwa, ale decyduje również o roli i pozycji państwa we wspólczesnym środowisku międzynarodowym.

21 B. Balcerowicz, Obrona państwa średniego, Warszawa 1997, s. 101-102. 
Bezpieczeństwo funkcjonalne to kategoria dotycząca wnikliwej obserwacji zachodzących zmian oraz ich dynamiki. To także ocena aspektów subiektywnych i obiektywnych mających bezpośredni wpływ na bezpieczeństwo, rozwój i funkcjonowanie podmiotu w środowisku międzynarodowym ${ }^{22}$. Istotą podejścia funkcjonalnego do bezpieczeństwa państwa i jego obywateli jest właściwa percepcja środowiska oraz wiedza na temat, jak podmiot polityki bezpieczeństwa postrzegany jest przez pozostałych aktorów. Umożliwia to skuteczne rozpoznanie wyzwań, eliminację zagrożeń oraz skuteczne wykorzystanie szans związanych $z$ istnieniem i przetrwaniem państwa oraz jego obywateli ${ }^{23}$.

Można zatem powiedzieć, że bezpieczeństwo państwa oraz narodu uzależnione jest od umiejętności wykrywania (dostrzegania wyzwań) i eliminacji źródeł zagrożeń (wykorzystania szans) powstających w obszarze wewnętrznym, jak i zewnętrznym państwa $z$ uwzględnieniem zachodzących między nimi interakcji. Jest ono wynikiem właściwego rozumienia istoty oraz realizacji walorów o znaczeniu autotelicznym, wynikających z przedstawionych powyżej obszarów. Od należytej realizacji wszystkich kategorii uwarunkowane jest przetrwanie oraz swobodny rozwój pojedynczego człowieka, społeczeństwa, narodu oraz państwa. Swym zakresem bezpieczeństwo obejmuje wspomniane wartości egzystencjalne pojedynczych uczestników, a także tworzy wartości wspólne dla całego systemu.

Powyżej poczynione spostrzeżenia, biorąc pod uwagę ograniczony charakter artykułu, mogą posłużyć jako wystarczający asumpt do pogłębienia rozważań o stanie bezpieczeństwa człowieka we współczesnym państwie oraz w środowisku międzynarodowym, a także do podkreślenia konieczności oraz istoty wzmożonej edukacji rozumianej jako stały proces „uczenia się, aktualizowania zdobytej wiedzy, podnoszenia kwalifikacji, nadążania za rozwojem nauki i techniki, wykształcenia poszanowania dla panujących w danej społeczności ideałów a przede wszystkim zapewnienia możliwości stałego rozwoju" w powyższym zakresie ${ }^{24}$. Biorąc pod uwagę, że szczególnego znaczenie w rozpatrywanym wymiarze nabiera edukacja dla bezpieczeństwa jednostki oraz państwa, za stosowne uważa się dokonanie pogłębionej refleksji w zakreślonym obszarze.

22 K. Lastawski, Racja stanu Rzeczypospolitej Polskiej, Warszawa 2000, s. 39-40.

Ibidem, s. 20.

24 J. Pólturzycki, Dydaktyka dla nauczycieli, Torun 1997, s. 113-115. 
W literaturze fachowej edukacja dla bezpieczeństwa ujmowana jest jako przysposobienie społeczeństwa, w tym wspólnoty szkolnej i akademickiej, do sprostania pojawiającym się zagrożeniom wynikającym z braku poszanowania podstawowych wartości wypełniających katalog praw człowicka oraz realizacji zadań związanych z ograniczeniem oraz eliminacją konsekwencji awarii, klęsk żywiołowych, katastrof zaistniałych w czasie pokoju, a także w trakcie działań wojennych ${ }^{25}$. Kategoria ta poza „zapewnieniem możliwości przeciwstawienia się zagrożeniom zewnętrznym i wewnętrznym niewątpliwie wiąże się z wykształceniem społeczeństwa zdolnego do radzenia sobie [...] z innymi zagrożeniami, wywierającymi wpływ na poziom [...] bezpieczeństwa personalnego i strukturalnego" społeczeństwa oraz państwa ${ }^{26}$. Paradygmat kształcenia dla bezpieczeństwa odrzuca korygowanie natury człowieka i sprowadzanie edukacji w tej dziedzinie wyłącznie do kategorii pokojowych. Aby równoważyć zachowania altruistyczne i agresywne człowieka, istotna jest także edukacja dla wojny i zbliżanie w ten sposób kształcenia w zakresic dla bezpieczeństwa do złotego środka, czyli stanu osiągnięcia względnej równowagi.

Obszar znaczeniowy pojęcia „edukacja dla bezpieczeństwa” należy poszerzyć o treści związane z kształtowaniem właściwej postawy moralnej, patriotycznej, obywatelskiej oraz obronnej jednostki i społeczeństwa. Ten specyficzny rodzaj edukacji wiąże się ściśle z oświatą, polityką oraz systemem zarządzania państwem. Zakresem swym obejmuje walory o charakterze ogólnoludzkim, uniwersalnym i humanitarnym, do których należy zaliczyć: podmiotowość, wolność, pluralizm, sprawiedliwość, równość wobec prawa, odpowiedzialność, godność, przestrzeganie ogólnie przyjętego systemu wartości społecznych oraz poszanowanie i tolerancję dla innych wartości, autonomię oraz samostanowienie. Istotnym aspektem poruszanego zagadnienia jest przeciwdziałanie nadmiernemu konsumpcjonizmowi i egoizmowi współczesnych społeczeństw oraz państw ${ }^{27}$. Micć czy być? - to pytanie, na które powinna odpowiedzieć współczesna edukacja oraz spoleczeństwo. Postawa „mieć" może prowadzić do wewnętrznego upadku współczesnego człowieka, a w konsekwencji do zerwania więzi społecz-

25 T. Siuda, K. Zaczek-Zaczyński, Edukacja obronna, [w:] Wspólczesne zagrożenia edukacji dla bezpieczeństwa, (red.) R. Stępień, Warszawa 1999, s. 98-99.

26 A. Pieczywok, Edukacja dla bezpieczeństwa wobec zagrożeń $i$ wyzwań wspótczesności, Warszawa 2012, s. 64.

27 W. Kitler, op. cit., s. 16 
nych, a także do atrofii systemu wartości oraz zaniku szacunku dla drugiego człowieka. Jednym z celów edukacji w powyższym rozumieniu winno zatem być dążenie do propagowania wartości istotnych dla dziedzictwa polskiej tradycji i kultury, poszerzania wiedzy z zakresu kultury innych regionów, pogłębianie i „umacnianic wartości humanistycznych określających pogląd na świat, styl i sposób życia, co oznacza zwiększenie roli i rangi nauk humanistycznych"28.

Wieloaspektowość omawianej problematyki powoduje, że bezpieczeństwo edukacyjne można uznać za kategorię o charakterze interdyscyplinarnym stanowiącą część systemu edukacji narodowej, w zakres której wchodzi edukacja dla bezpieczeństw: politycznego, militarnego, gospodarczego, publicznego, psychospołecznego i ekologicznego. Dla właściwego zrozumienia warto zwrócić uwagę na bardziej szczegółową charakterystykę zaproponowanego przez B. Rudnickiego podziału edukacji dla bezpieczeństwa, która prezentuje się następująco, jako edukacja dla:

- bezpieczeństwa politycznego to zakres oddziaływań oświatowo-wychowawczych, zmierzających do kształtowania kultury politycznej społeczeństwa oraz postaw wobec pojawiających się wyzwań i zagrożeń;

- bezpieczeństwa militarnego to ogół oddziaływań obejmujących kształcenie i wychowanie obronne społeczeństwa nakierowane na zachowanie niepodległości narodu i państwa oraz ochrony życia i ludzi w stanach zagrożenia wojennego i wojny;

- bezpieczeństwa gospodarczego to działania oświatowo wychowawcze nakierowane na poszerzenie i kształtowanie świadomości ekonomicznej i postaw wobec zagrożeń gospodarczych dla społeczeństwa;

- bezpieczeństwa publicznego to ogół oddziaływań oświatowo-wychowawczych, zmierzających do kształtowania świadomości prawnej społeczeństwa oraz postaw i zachowań w sytuacjach zagrażających obywatelom i porządkowi publicznemu;

- bezpieczeństwa psychospołecznego to ogół oddziaływań zmierzający do kształtowania moralności społeczeństwa oraz postaw wobec zagrożeń psychospołecznych;

28 Polska w obliczu wspólczesnych wyzwań cywilizacyjnych, Warszawa 1991, s. 35-36. 
- bezpieczeństwa ekologicznego to ogół oddziaływań oświatowo-wychowawczych, zmierzających do harmonijnego współżycia ludzi z przyrodą oraz postaw i zachowań w sytuacjach zagrożeń ekologicznych ${ }^{29}$.

Powyższy zbiór można by uzupełnić o konieczność edukacji w zakresie kształtowania świadomości rozpoznawania zagrożeń niesymetrycznych, często charakteryzowanych jako niemilitarne.

Analiza powyższego materiału pozwala na konstatację, że fundamenty edukacji dla bezpieczeństwa wywodzą się i czerpią wiedzę z koncepcji i teorii filozoficznych, psychologicznych, pedagogicznych oraz socjologicznych odpowiedzialnych za rozpoznanie natury czlowieka i potrzeb państwa. Odnajdują swe oparcie w aksjologii i etyce, na której winno być budowane bezpieczeństwo jednostki, państwa i współczesnego świata. Jak zauważył A. Pieczywok, w procesie wyjaśniania znaczenia edukacji kardynalne znaczenie mają motywy ludzkich zachowań i postaw. Równie ważna jest teoria potrzeb, które dla celów tego opracowania należy rozumieć jako uświadomione (wyedukowane) dążenie do przygotowania jednostki i ,państwa na wszystkich szczeblach i we wszystkich dziedzinach jego organizacji dla ciągłej skutecznej ochrony i obrony interesów i wartości narodowych przed zagrożeniami militarnymi i niemilitarnymi w warunkach niepewności i postępu’30, gwarantujące trwanie i rozwój narodu oraz państwa w długim okresie.

Zanim przejdziemy do dalszych dociekań nad zarysowaną problematyką, należy poczynić krótką refleksję nad charakterystyką, sposobem oraz poziomem edukacji wspólczesnego człowieka. Pomimo XXI wieku i wprowadzenia do edukacji systemów dydaktycznych adaptacyjnych oraz innowacyjnych ${ }^{31}$ większość jednostek edukacyjnych hołduje jeszcze XVIII-wiecznym zasadom i zgodnie $\mathrm{z}$ tradycją nastawiona jest na przekazywanie gotowej wiedzy w procesie kształcenia (pewnym odstępstwem od przywołanej zasady z całą pewnością są uczelnie wyższe). Przyjęty kanon

29 Zob. B. Rudnicki, Edukacja dla bezpieczeństwa i jej interpretacja, [w:] Edukacja dla bezpieczeństwa, materiaty z konferencji naukowej 23-24 maja 1994, (red.) R. Stępień, Warszawa 1994, s. 63; A. Szymonik, Organizacja funkcjonowanie systemów bezpieczeństwa, Warszawa 2011.

30 J. Marczak, Spoleczeństwo w tworzeniu bezpieczenistwa narodowego, [w:] Podstawy bezpieczeństwa narodowego Polski w erze globalizacji, (red.) R. Jakubczak, Warszawa 2008, s. $98-106$.

31 Z. Łomny, Czlowiek i edukacja wobec przemian globalnych, Radom 1996, s. 96. 
ogranicza się do metody podającej nauczania, kształtując w ten sposób jednostkę bezrefleksyjną, a jednocześnie posiadającą bezmiar wiedzy encyklopedycznej, z której nie potrafi właściwie skorzystać. Zaniedbanie to w większości przypadków prowadzi do wykształcenia człowicka oświeconego, lecz nieumicjącego wykorzystać twórczo i intuicyjnic procesu myślenia $^{32}$. Procesowi bezrefleksyjnego myślenia oraz przyjmowania informacji, takimi jakie są, sprzyjają także dzisiejsze media. Wykształcone w ten sposób cechy nie odnajdują zastosowania we współczesnym, dynamicznym, wypełnionym zmianami pchanymi kolejną falą cywilizacji świecie. Zgodnie z tym, co zauważył A. Toffler, „edukacja wypływa z obrazu przyszłości i równocześnie sama kształtuje ten obraz" ${ }^{\prime 33}$. Istotą dzisiejszej edukacji winno więc być ukształtowanie postawy badawczej jednostki transgresyjnej umiejącej rozpoznawać wyzwania, zagrożenia oraz szanse, a także związany z nimi poziom ryzyka, i odpowiednio je interpretować, odkrywać nową rzeczywistość.

Punktem wyjścia dla dalszych rozważań o znaczeniu edukacji w procesie podnoszenia progu bezpieczeństwa dla pojedynczego czlowieka oraz narodu można uznać wydarzenia roku 1989 określane mianem ,jesieni ludów". Efektem ich było odzyskanie pełnej podmiotowości państw Europy Środkowej, a także załamanie się dychotomii świata wyznaczonej przez dwa mocarstwa: USA oraz ZSRR. Rozpad sowieckiego bloku oraz samego ZSRR, poza zmianami geopolitycznymi na mapic Europy i Azji, przyczynił się do rozbudzenia nacjonalizmów (przykładem niestabilności był „kocioł bałkański") oraz wzrostu zagrożenia proliferacji broni masowego rażenia (BMR). Obok rozprzestrzeniania BMR do rangi zagrożenia dla społeczeństw i narodów urasta chęć posiadania arsenałów jądrowych przez państwa Bliskiego Wschodu oraz kontynentu azjatyckiego ${ }^{34}$. Niebezpieczny w skutkach dla człowieka jest stały wzrost przemytu i nielegalnego handlu bronią. Wiąże się z tym przekazywanie państwom zbójeckim nowoczesnych technologii, w tym technologii podwójnego przeznaczenia. Pośród niebez-

32 J. Kozielecki, Czlowiek wielowymiarowy, Warszawa 1996, s. 32-33.

33 A. Toffler, Learning for Tomorrow. The Role of the Future in Education, New York 1974, s. 5.

34 M. Kaczmarski, Problem proliferacji broni masowego rażenia, [w:] Świat wobec wspótczesnych wyzwań i zagrożen, (red.) J. Symonides, Warszawa 2010, s. 375-389; T. Strulak, Niebezpieczeństwo rozprzestrzeniania broni masowego rażenia, [w:] Organizacja Narodów Zjednoczonych. Bilans i perspektywy, (red.) J. Symonides, Warszawa 2006, s. 484. 
pieczeństw związanych z tym procederem najczęściej wymienia się możliwość wystąpienia zagrożenia użycia broni masowego rażenia w stosunku do państw demokratycznych oraz kierowanych przez nie misji wojskowych uczestniczących w walce $z$ globalnym terroryzmem, a także w operacjach przywracania pokoju $w$ różnych rejonach świata. Istotnym wyzwaniem jest wynikające $z$ powyższego bezpośrednie zagrożenie dla społeczności lokalnych. Niepokojącym zjawiskiem, będącym zagrożeniem dla cywilizacji świata zachodniego, jest dążenie państw przestępczych oraz organizacji terrorystycznych do zmiany równowagi sił przez wejście w posiadanie wspomnianych technologii i broni masowego rażenia. Następstwem tego, poza pojawieniem się nowych odmian terroryzmu, jak np. „,nuklearny szantaż", może być zanik powszechnie uznawanych norm i wartości człowieka, a w efekcie jego zagłada ${ }^{35}$.

Znaczącym wydarzeniem istotnym dla współczesnej edukacji, z którym należy łączyć zmianę perspektywy postrzegania współczesnych zagrożeń dla bezpieczeństwa człowieka i świata, niewątpliwie był atak Al-Kaidy na Nowy Jork w dniu 11 września 2001 r. Narzędziem niosącym śmierć, z jakiego w tym przypadku skorzystali terroryści, były samoloty pasażerskie.

Jako zjawisko terroryzm nie jest niczym nowym, a pierwsze wzmianki na jego temat sięgają starożytności. Jednym z najwcześniej zapisanych w historii aktów terrorystycznych było spalenie świątyni Artemidy w Efezie w roku 356 p.n.e. Czynu tego dokonał Herostrates, żywiąc nadzieję, że jego imię dzięki temu przetrwa po wsze czasy. Za akt terrorystyczny uważa się także morderstwo Juliusza Cezara dokonane w czasie idów marcowych w roku 44 p.n.e. Po broń tę z ochotą sięgały ugrupowania sykariuszy i zelotów w walce przeciwko Rzymowi w I wieku n.e. ${ }^{36}$ Można zatem przyjąć, że terroryzm to wielopłaszczyznowe zjawisko historyczne o dynamicznym charakterze występujące na przełomach wieków w różnych postaciach. „Terroryzm przeznaczony jest dla tych, którzy patrzą, a nie dla tych, którzy stali się jego ofiarami. Terroryzm jest teatrem [...], przemocą dla efektu, ale nie dla wyniku [...]. W rzeczywistości ofiara może być zupełnie nie zwią-

35. J. Krause, The Proliferation of Weapons of Mass Destruction: The Risks for Europe, Chaillot Paper 1996, No. 5, s. 5-21.

36 J. Tomasiewicz, Terroryzm na tle przemocy politycznej. Zarys encyklopedyczny, Katowice 2000 , s. 41-42. 
zana z celem działania terrorystów"37. Głównym dążeniem działań grup terrorystycznych jest w związku z tym maksymalna skuteczność aktu. Przypadkowe i nieprzypadkowe ofiary powiększają szkodliwość społecznych, gospodarczych i ekologicznych skutków. Terroryzm może być postrzegany jako forma działań wojennych lub element walki psychologicznej ${ }^{38}$.

Celem ataku jest zwykle zwrócenie uwagi na istniejący problem o politycznym zabarwieniu. Sam akt nakierowany jest na wywołanie oczekiwanego stanu psychicznego obserwatorów. Na gruncie nauk zajmujących się badaniem tego zjawiska istnieje wiele definicji. Encyklopedia PWN terroryzm charakteryzuje jako: ,umotywowane ideologicznie, planowane i zorganizowane działania pojedynczych osób lub grup skutkujące naruszeniem istniejącego porządku prawnego, podjęte w celu wymuszenia od władz państwowych i społeczeństwa określonych zachowań i świadczeń, często naruszające dobra osób postronnych"39. Za jedną z najbardziej kompleksowych uważa się definicję sformułowaną przez Mariana Flemminga. Według niego ,terroryzm to umyślne działanie stanowiące naruszenie prawa karnego i zmierzające w drodze aktów przemocy lub zagrożenia tymi aktami do zastraszania organów państwa lub znacznych odlamów społeczeństwa oraz do wymuszenia określonego postępowania"40.

Zjawiskiem towarzyszącym terroryzmowi jest konflikt asymetryczny. Z sytuacją o takim charakterze mamy do czynienia, gdy jedna z walczących stron na skutek ,dysproporcji potencjałów militarnych i innych zasobów wykorzystywanych w konflikcie oraz odmienności kulturowych, decyduje się na zastosowanie metod, środków i taktyk niekonwencjonalnych z punktu widzenia przeciwnika. Konflikt asymetryczny może toczyć się pomiędzy państwami lub pomiędzy państwem i zewnętrznym podmiotem pozapaństwowym, np. organizacją terrorystyczną," ${ }^{4}$. Za przykład konfliktu asymetrycznego może posłużyć wojna między Stanami Zjednoczonymi a Irakiem lub wojna USA i koalicjantów ze światowym terroryzmem.

37 B. M. Jenkins, International Terrorism. A New Mode of Conflict. California Seminar on Arms Control and Foreign Policy, Los Angeles 1975, s. 1.

38 P. Sienkiewicz, 25 wykladów, Warszawa 2013, s. 210.

39 Nowa encyklopedia powszechna, t. VI, Warszawa 1997, s. 370.

40 M. Flemming, Terroryzm polityczny w międzynarodowym prawodawstwie, Wojskowy Przegląd Prawniczy 1996, nr 1, s. 3.

41 M. Madej, Zagrożenia asymetryczne bezpieczeństwa państw obszaru transatlantyckiego, Warszawa 2007, s. 44-74. 
Postrzeganie zagrożenia uległo zmianie po zamachach na Word Trade Center oraz Pentagon. Przyczynil się do tego fakt, że po raz pierwszy uderzenie skierowane zostało w fundamenty państwa. Konsekwencją wydarzenia było wypowiedzenie wojny terroryzmowi przez administrację USA. Odpowiedzią zaś były kolejne zamachy wyreżyserowane przez członków Al-Kaidy, która stała się w ten sposób synonimem globalnego terroryzmu. Działalność grup o podobnym zabarwieniu można zaobserwować na terenie Rosji, gdzie bojownicy czeczeńscy w podobny sposób starali się wyeksponować swoje racje $\mathrm{e}^{42}$. O tym, że problem ten istnieje i może się pojawić niespodziewanie w każdym regionie świata, mogą zaświadczyć ostatnie wydarzenia z Wołgogradu (Rosja), gdzie w rezultacie dwóch zamachów zginęły 34 osoby ${ }^{43}$.

Omawiając zjawisko terroryzmu jako jedno z edukacyjnych wyzwań XXI w. dla bezpieczeństwa człowieka, nie należy pomijać działalności „samotnych wilków”. W tym celu na bliższą uwagę zasługuje norweski chrześcijański fundamentalista A. Breivik. Dokonując 22 lipca $2011 \mathrm{r}$. dwóch zamachów w Oslo na siedzibę premiera oraz na wyspie Utoya łącznie pozbawił życia 77 osób. W pierwszym przypadku za broń posłużyły mu ładunki wybuchowe, w drugim zaś broń automatyczna ${ }^{44}$. W tym miejscu należy poczynić uwagę, że działalnością Breivka już przed zamachem interesowały się tajne służby. Członkowie organizacji terrorystycznych w większości przypadków używają jako narzędzi prymitywnych środków wybuchowych oraz broni. Nic nie stoi jednak na przeszkodzie, aby arsenał ten poszerzyć o środki chemiczne, toksyny oraz odpady promieniotwórcze. Za miejsce ataku w podobnym przypadku może wystarczyć ujęcie wody. Podobnie groźną w skutkach bronią, o czym przekonaliśmy się już w XX wieku, może się okazać ideologia, szczególnie o zabarwieniu fundamentalistycznym.

42 R. Zięba, Nowe wyzwania..., s. 346-347. We wspomnianym zamachu w Nowym Jorku oraz Waszyngtonie zginęly 2752 osoby. W wyniku zakrojonych na szeroką skalę dzialań przeciwko „koalicji chętnych” zorganizowanej do zwalczania terroryzmu islamskiego do kolejnych zamachów przeprowadzonych przez Al-Kaidę doszło 11 marca 2014 r. w Madrycie (191 ofiar), 7 lipca 2005 r. w Londynie (52 ofiary).

$43 \mathrm{http}: / /$ polish.ruvr.ru/2013 12 31/Spolecznosc-miedzynarodowa-jest-wstrzasnieta-zamachami-wWolgogradzie [dostęp: 3 I 2014 r.].

$44 \mathrm{http}: / /$ pl.wikipedia.org/wiki/Zamachy w Norwegii \%282011\%29 [dostęp: 3.01 .2014 r.]. 
Do wyzwań o podobnej skali jak przedstawione powyżej, z jakimi powinna się mierzyć dzisiejsza edukacja, rozwijając działalność w obszarze poprawy i zapewnienia bezpieczeństwa człowieka oraz społeczeństwa, jest transnarodowa przestępczość zorganizowana. Szkodliwe skutki tego procederu mogą wpływać nie tylko na bezpieczeństwo jednostek i grup społecznych, ale także destabilizować państwa. Obszarem działań pozapolitycznych grup o wspomnianym charakterze jest: przemyt narkotyków, handel ludźmi oraz ludzkimi organami, handel bronią, korupcja ${ }^{45}$. W obszarze politycznym działalność ta sprowadza się do celowego pobudzania niepokojów społecznych. Dążeniem jest destabilizacja państwa, uniemożliwienie zapewnienia bezpieczeństwa obywatelom przez legalnie działające rządy oraz administracje państwowe, a w efekcie przejęcie nad nim kontroli i wprowadzenie dyktatury lub reżimu o zbójeckim charakterze. Za przykłady podobnego działania mogą posłużyć upadłe państwa: Ruanda, Somalia, Liberia ${ }^{46}$. Do grona takich państw można zaliczyć także Libię, która od dwóch i pół roku zmaga się z falą niepokojów. Rebelianci po obaleniu Kadafiego i akcie wyborczym mającym zagwarantować spokój nie odłożyli broni, a kraj stopniowo pogrąża się w anarchii. Uzbrojone bandy zmierzając po zyski z bogactwa, jakim w tym regionie jest ropa, zajęły rządowe budynki. Z wywiadu udzielonego przez byłego premiera Libii Ali Zajdana wynika, że na terenie państwa można zaobserwować ogniska Al-Kaidy ${ }^{47}$. Do kategorii państw słabych o niestabilnym systemic politycznym z regionu euroazjatyckiego można zaliczyć: Afganistan, Gruzję, Mołdawię, Kirgistan, Tadżykistan. Ostatnie wydarzenia pozwalają na konstatację, że do grona tego zbliża się Ukraina.

Jedną z dziedzin działalności przestępczych grup transnarodowych jest cyberterroryzm oraz cyberprzestępczość. Podmiotami najbardziej narażonymi na ataki w tej płaszczyźnie są państwa najbardzicj rozwinięte. Ofiarą cyberprzestępczości może jednak paść każdy czlowiek korzystający z sieci. Specyfiką tego zagrożenia jest ,aterytorialność” oraz „oderwanie od uwarunkowań fizycznych". Pośród najczęściej wymienianych zagrożeń, prze-

$45 \mathrm{Ph}$. Williams, Transnational criminal organizations and international security, Survival 1994 , No. 1, s. 96-13.

46 M. Leszczyński, Bezpieczenistwo spoleczne Polaków wobec wyzwań XXI wieku, Warszawa 2011; R. Zięba, Nowe wyzwania..., s. 347-348.

$47 \mathrm{http}: / /$ wiadomosci.onet.pl/swiat/byly-premier-libii-ostrzega-zachod/cx8qg [dostęp: 27.03 .2014 r. $\operatorname{godz}$ 15:49]. 
prowadzonych z użyciem sieci internetowej, motywowanych politycznie pojawiają się: atak na infrastrukturę krytyczną, zastraszenia rządów w celu uzyskania oczekiwanych zmian politycznych, dezinformacja, blokowanie dostępu do niezbędnych danych, kradzież najnowszych technologii. Dla przeciętnego obywatela działalność ta może skutkować kradzieżą własności intelektualnej, uniemożliwieniem dostępu do własnych danych itp. ${ }^{48}$ Do zagrożeń płynących z sieci należy zaliczyć: możliwość przekazywania i uzyskiwania informacji o celach aktów terrorystycznych, zasadach pozyskiwania ochotników do walki, sposobach konstruowania bomb oraz finansowania przedsięwzięć związanych z tym zjawiskiem ${ }^{49}$. Najczęściej podaje się cztery główne kategorie potencjalnych źródeł cyberterroryzmu:

- typowe grupy terrorystyczne;

- „państwa zbójeckie”, do których mogą dołączyć inne kraje;

- sympatycy terrorystów oraz antyamerykańscy hakerzy;

- poszukiwacze silnych wrażeń, niekierujący się przesłankami politycznymi lub ideologicznymi ${ }^{50}$.

Rezultatem cyberterroryzmu i przestępczości w cyberprzestrzeni mogą być: destabilizacja państw, upadek rządów oraz utrata możliwości wpływania na bezpieczeństwo państwa oraz społeczeństwa ${ }^{51}$.

Równie ważnym dla współczesnej edukacji w zakresie bezpieczeństwa, biorąc pod uwagę przywołane powyżej wszystkie niekorzystne konsekwencje załamania się dychotomii świata w roku 1989, był weześniejszy (pochodzący z 1973 r.) zbagatelizowany do pewnego stopnia raport Klubu Rzymskiego. Sporządzony przez grupę wybitnych naukowców podejmował próbę scharakteryzowania najważniejszych wyzwań i zagrożeń, jakie przed człowiekiem stawia przyszłość. Był jednocześnie przestrogą i zachętą do wdrożenia w życie procesów umożliwiających odwrócenie destrukcyjnych i samounicestwiających się działań człowicka, czyli wykorzystania nadarzających się szans. Obejmował swym zakresem problematykę dotyczącą możliwości oraz barier dla ciągłości cywilizacyjnego wzrostu. Pośród głównych kategorii przedstawionej analizy, której twórcy za punkt wyjścia obrali ocenę kierunków i skutków przemian związanych z rozwo-

\footnotetext{
48 M. Madej, Cyberterroryści..., s. 390-406.

49 P. Sienkiewicz, op. cit., s. 213.

Ibidem.

51 E. Bendyk, Antymatrix. Czlowiek w labiryncie sieci, Warszawa 2004.
} 
jem cywilizacji, pojawiły wyzwania: demograficzne, niedożywienie, głód, nadmierna urbanizacja i industrializacja, deficyt energetyczny, wyczerpanie surowców oraz degradacja środowiska naturalnego na skutek nadmiernej eksploatacji. Raport nawoływał do wypracowania sensownej polityki gwarantującej bezpieczeństwo przyszłemu światu oraz do wykorzystania rezerw naturalnych i kierowania dalszym rozwojem cywilizacji w racjonalny sposób. Jako widmo możliwych konfliktów wskazywał na wzrastającą przepaść między bogatą Północą i biedniejącym Południem ${ }^{52}$.

Kolejny raport dla Klubu Rzymskiego, pt. Ludzkość w punkcie zwrotnym, dotyczył koncepcji zrównoważonego rozwoju świata. Skupiał się na zaawansowaniu cywilizacyjnym poszczególnych regionów, dynamice ich rozwoju oraz na barierach, możliwościach i zagrożeniach związanych z poddanymi analizie aspektami. Jako główne zagrożenie dla przyszłości twórcy raportu przedstawili: nadmierny wzrost ludności świata, dysproporcje w rozwoju gospodarczym, problemy wynikające z niedostatku żywności oraz kryzys energetyczno-surowcowy. Jednocześnie przyczyn kryzysów przyszłości upatrywali w nadmiernej dewastacji i niekontrolowanym wykorzystaniu zasobów środowiska naturalnego ${ }^{53}$.

Następne opracowanie dla Klubu Rzymskiego sporządzone w roku 1976, pt. O nowy ład międzynarodowy, wskazywało na istnienie bezpośredniego związku między ładem społecznym i gospodarczym. Dokonana analiza potwierdziła, że wzrost gospodarczy jest uzależniony od poprawy ,jakości” człowieka. „Człowiek »zastany [...] nie może tworzyć postępu czy wzrostu" ${ }^{\prime 5}$. Spostrzeżenie to odnosiło się do grupy państw ówcześnie postrzeganych jako państwa Trzeciego Świata, lecz zakresem swym obejmowało także państwa bloku sowieckiego. W pewnym sensie konsekwencją analizy dokonanej w raporcie $O$ nowy lad międzynarodowy było kolejne opracowanic przygotowane dla Klubu Rzymskiego, pt. Uczyć się bez granic. Autorzy raportu za fundamentalny warunck dla rozstrzygania o przyszłych globalnych problemach świata uznali konieczność edukacji. Hasło „ucz się albo giń" sformułowane przez autorów wskazuje na istotę edukacji we wszystkich zarysowanych w tym opracowaniu problemach. Jedną z na-

52 D. H. Meadows, D. L. Meadows, J. Randers et al., Granice wzrostu. Pierwszy raport dla Klubu Rzymskiego, Warszawa 1973.

53 M. Mesarovic, E. Pestel, Ludzkość w punkcie zwrotnym, Warszawa 1978.

54 J. Timbergen, O nowy lad międzynarodowy, Warszawa 1978. 
czelnych tez raportu stanowi konkluzja, że człowiek niezależnie od koloru skóry, płci, wieku, pochodzenia społecznego posiada nieograniczone możliwości do pogłębiania wiedzy. Proces edukacji według autorów odgrywa konstytutywne znaczenic dla utrwalania praw człowieka i jego przyszłego rozwoju. Jest także warunkiem jego trwania ${ }^{55}$.

Bardzo zbliżony obraz przyszłości, traktowany przez wielu jako wymysł czystej fantazji, stworzył A. Toffler. „Przez ogromne połacie świata przewala się dziś potężna fala, tworząc nowe, często dość osobliwe środowisko do pracy, zabawy, małżeństwa, wychowywania dzieci, wreszcie - życia na emeryturze. W tym oszałamiającym kontekście biznesmeni rzucają się pod prąd niezrozumiałych trendów gospodarczych, prestiż polityków wzrasta i upada w zawrotnym tempie, raz w górę, raz w dół, a uniwersytety, szpitale $\mathrm{i}$ inne instytucje rozpaczliwie i bezskutecznie zmagają się $z$ inflacją. A kiedy rodzina, Kościół, państwo - owe szalupy ratunkowe człowieka - miotane są przez obłąkańcze wiry, zaczynają pękać z trzaskiem dawne systemy wartości" ${ }^{56}$. Dzisiejszy świat pozbawiony idei, narażony na upadek rodziny nuklearnej wskutek zaniku wspomnianych powyżej waloru określających jego kodeks moralny, targany kryzysami odnajdującymi swoje podłoże w fundamentalizmach lub kultach oraz odradzających się separatyzmach z wizją groźby kryzysu energetycznego może przerażać. Powyższy opis nie odbiega od tego, co możemy dzisiaj zobaczyć, otwierając okno, czytając gazetę, słuchając radia lub oglądając telewizję. Siłę tego przekazu zrozumieć można lepiej, gdy uświadomimy sobie, że jest on wynikiem żmudnej obserwacji zachodzących zmian i właściwego prognozowania przyszłości. Z całą pewnością na wielu twarzach pojawi się zdziwienie, gdy dowiemy się, że powstała ponad 30 lat temu w okresie wielkiej prosperity zachodu. Dalej A. Toffler podkreśla, że zachodzące wokół nas zmiany niosące ze sobą wyzwania oraz zagrożenia są wynikiem budowanej przez szereg lat globalnej sieci zależności określonej przez H. M. McLuhana mianem ,globalnej wioski". Można zaryzykować stwierdzenie, że wizja jest spełnieniem pogoni za dobrem określanym „mieć" i nieuwzględniania tego, co pozwala nam „być”. Ta z pozoru katastroficzna eksplanacja to efekt zderzenia fal cywilizacyjnych, którego skutki możemy obserwować dzisiaj.

55 J. Botkin, M. Elmandjra, M. Malitza, Uczyć się bez granic. Jak zewrzeć ,lukę ludzka”, Warszawa 1982.

$56 \quad$ A. Toffler, Trzecia..., s. 25. 
Obszar zakreślony powyżej stanowi równie ważne wyzwania dla współczesnej edukacji jak zagrożenia niesione przez nowo powstające odmiany terroryzmów. Na pierwszy plan dalszych rozważań można wysunąć ekonomiczne bezpieczeństwo państwa oraz wynikające z procesu globalizacji związane z nim pojawiające się zagrożenia cywilizacyjne. Wagę oraz charakter przywołanej kategorii podkreśla jej wielopłaszczyznowość. W większości społeczeństwu ekonomia kojarzy się z bogactwem i możliwościami rozwoju lub biedą i zastojem. Zwykle za jeden z najważniejszych wyznaczników bogactwa państwa w tej kategorii uważa się jego zasobność w zróżnicowane surowce mineralne oraz zdolność uzyskiwania z nich produktów wysokoprzetworzonych. Na pierwszym micjscu stawia się w tym względzie bezpieczeństwo energetyczne, które w połączeniu z wysoko rozwiniętym przemysłem opartym na najnowszych technologiach poszerzają znacznie możliwości rozwoju państwa i społeczeństwa we wszystkich płaszczyznach $^{57}$. Brak surowców mineralnych, poza ograniczeniem zdolności rozwoju, może się wiązać z próbą podporządkowania podmiotu politycznego innemu aktorowi stosunków międzynarodowych (szantaż ekonomiczny). Powyższa sytuacja niesie za sobą bezpośrednie zagrożenie dla przestrzeni suwerenności zagwarantowanej wyłącznie dla państwa oraz dla wolności jego obywateli.

Międzynarodowe powiązania gospodarcze powodują, że globalny rynek umożliwia wielu aktorom państwowym, w tym także organizacjom transnarodowym, spekulowanie aktywami banków zglobalizowanej części świata. Skalę problemu unaocznił kryzys finansowy 2008 r. Jego skutki (dostrzegalne do tej pory) doprowadzily do częściowej destabilizacji politycznej wielu państw, powodując bezpośrednie zagrożenie dla ich obywateli ${ }^{58}$. Ujawniająca się na wielu rynkach zapaść podkreśliła siłę oraz przenikanie się wzajemnych powiązań międzynarodowych. Wydarzenia z tym związane są wystarczającym asumptem do wzmożonej edukacji w tym obszarze. Celem jej winno być właściwe i odpowiednio wczesne postrzeganie pojawiających się wyzwań oraz przeciwdzialanie tego rodzaju zagrożeniom. Bezpieczeństwo ekonomiczne państwa jest ściśle powiązane z sferą socjalną społeczeństwa. Jego zamożność oraz możliwości stałego rozwoju, w tym

57 K. Pronińska, Ewolucja zagrożeń bezpieczeństwa energetycznego, [w:] Świat wobec wspótczesnych wyzwań i zagrożen, (red.) J. Symonides, Warszawa 2010, s. 407-427.

58 R. Zięba, Nowe wyzwania..., s. 350. 
edukacji, decydują nie tylko o nastrojach społecznych, ale przekładają się także na demografię, czyli możliwości odnawialne narodu. Duże znaczenie dla właściwego rozwoju w tym względzie ma ekologia. Alarmującym problemem staje się wzrastający deficyt słodkiej wody, wylesianie oraz nadmierna urbanizacja. Przesadna eksploatacja ekosystemu prowadzi do erozji i pustynnienia obszarów. W dłuższej perspektywie degradacja środowiska może się stać przyczyną migracji na dużą skalę. Zachowane we właściwym stanie ekosystemu jest nie tylko gwarantem wspomnianych możliwości odnawialnych oraz rozwoju narodu i państwa, ale jawi się jako jedno z najważniejszych wyzwań współczesnej edukacji ${ }^{59}$.

Ekonomia to także wynikające z niej podziały na „bogatą Północ” i „,biedne Południe”. Pomimo powszechnej globalizacji nie brak regionów świata, gdzie głód jest rzeczą powszechną. Skrajna bieda spowodowana deficytem żywności oraz wody państw Afryki i Azji popycha tamtejszą ludność do konfliktów. Jedną z przyczyn zarysowanej sytuacji wskazanego regionu jest niedostateczna edukacja społeczeństwa. Charakterystyczny dla obszarów „biednego Południa” jest także brak respektowania fundamentalnych praw człowieka i wynikający z niego brak podmiotowości obywateli. Istnieje zatem stała groźba destabilizacji wspomnianych regionów. Wiąże się to możliwością wybuchu konfliktów oraz ich eskalacją na inne części świata. Zjawiskami towarzyszącymi takim stanom są zwykle exodus i nielegalna emigracja ludności państw narażonych na podobne kataklizmy ${ }^{60}$.

Najczęściej celem emigrantów współczesnego świata są państwa Europy Zachodniej oraz USA. Przyczyn współczesnych migracji należy poszukiwać we wspomnianych powyżej: konfliktach, ubóstwie oraz braku poszanowania dla niezbywalnych praw człowieka. Współczesny exodus dotyczy także państw rozwiniętych. Powodowany jest zwykle wysoką skalą bezrobocia w niektórych regionach oraz poszukiwaniem możliwości awansu społecznego w obszarze zgodnym z kierunkiem wykształcenia. Wymienione aspekty trwale wiążą się z bezpieczeństwem pojedynczej komórki społecznej, jaką jest rodzina. Mają jednakże wpływ na bezpieczeństwo państwa.

59 Z. W. Kundzelewicz, P. Kowalczyk, Zmiany klimatu i ich skutki, Poznań 2008, s. 9-56; J. Boryczka, M. Stopa-Boryczka, K. Kożuchowska, Zmiany klimatu wywolane przez czlowieka, [w:] Katastrofy i zagrożenia we wspótczesnym świecie, Warszawa 2008, s. 70-82.

60) J. Nakonieczna, Migracje międzynarodowe jako wyzwanie we wspólczesnym świecie, [w:] Świat wobec wspólczesnych wyzwań i zagrożeń, (red.) J. Symonides, Warszawa 2010, s. 315-330. 
Na szczególną uwagę poza obszarem finansowym zasługuje różnorodność kulturowa. Heterogeniczność odnosi się do środowisk emigracyjnych stających się coraz częściej zjawiskiem powszechnym w państwach rozwiniętych zglobalizowanego świata. Wielokulturowość nie może być postrzegana jako problem, rodzi jednak nowe wyzwania. Dotyczą one wzajemnego poszanowania dla uznawanych wartości, symboli religijnych, koloru skóry. Tym samym za bardzo istotne należy uznać podniesienie edukacji we wspomnianym zakresie ${ }^{61}$. Należy jednak pamiętać, że pośród celów stawianych dzisiejszemu szkolnictwu szczególną uwagę należy zwrócić na znajomość własnej historii oraz historii regionu, związanej z nią literatury oraz sztuki. Przekazywane wartości związane z kulturą rozumianą jako ,zapis chronologii narodu", podkreślające tożsamość oraz dziedzictwo narodowego stanowią jeden z głównych wyznaczników bezpieczeństwa narodu oraz państwa. Pozwalają także lepiej zrozumieć przyszłośćć

W kontekście prowadzonych rozważań warto także zwrócić uwagę na wypadki związane $z$ ancksją przez Rosję stanowiącego autonomiczną część Ukrainy Krymu, która stała się faktem 21 marca 2014 r. Z dużą dozą prawdopodobieństwa można powiedzieć, że wydarzenia te, poza upadkiem zbiorowego modelu bezpieczeństwa, który był próbą wprowadzenia rządów prawa mającego stać na straży pokoju, a jednocześnie „obezwładniać i karać agresorów", niosą za sobą konsekwencje w postaci odnowienia podziału świata i powrotu do dwubiegunowości lub konfrontacji o kolejną dominację. Przyczyną tego z pewnością nic była wadliwość zaproponowanego przez prezydentów Busha i Mitteranda ${ }^{63}$ nowego ładu systemu światowego, ale geopolityczne cele i ambicje Rosji. Zanim jednak Rosja zdecydowała się na ten swoisty anschluss, wcześniej musiała rozważyć i dokonać fundamentalnie strategicznego wyboru dotyczącego stosunków z Ameryką. Strategiczność decyzji polegała na tym, że władze Kremla, decydując się na pogwałcenie prawa międzynarodowego dotyczącego integralności, suwerenności i niepodległości Ukrainy, musiały rozważyć charakter przyszłych

${ }^{61}$ J. Jaskiernia, Bezpieczeństwo państwa a ochrona praw i wolności jednostki, [w:] Świat wobec wspólczesnych wyzwań i zagrożeń, (red.) J. Symonides, Warszawa 2010, s. 274-289.

62 K. Grabowski, Znaczenie kultury i oświaty w procesie odzyskiwania racji stanu przez Polske Rzeczpospolita, [w:] Zblizenia cywilizacyjne. Edukacja, kultura, polityka, (red.) A. Sepkowski, Wloclawek 2013, s. 167.

63 P. Hassner, Koniec pewników; esejo wojnie, pokoju i przemocy, Warszawa 2002, s. 28. 
stosunków ze światem zachodnim, a przede wszystkim z USA, „zdecydować, czy Stany Zjednoczone sa jej wrogiem czy przyjacielem" ${ }^{\text {". }}$.

Wcześniejsza agresja na Gruzję, wspieranie Naddniestrza i obecny atak na Ukrainę wskazują, że Rosja nie dążyła i nie dąży do przekształcenia się w państwo demokratyczne w zachodnim stylu, ale jej głównym celem jest odbudowa potęgi i utworzenie nowego imperium euroazjatyckiego. Nowe trendy napływające $z$ państw poddających się fali demokracji zostały pokonane przez „rosyjski związek kapitalizmu z autorytaryzmem anarchicznym" i skorumpowaniem ${ }^{65}$. Tym samym niepodległa i suwerenna Ukraina przesuwająca swój ciężar w kierunku demokracji zachodniej i pretendująca do UE, o czym wspominał wiele lat temu Z. Brzeziński, nie może być wygodnym partnerem na euroazjatyckiej szachownicy dla Rosji. W dniu 20 listopada 1996 r. doradca Borysa Jelcyna Dimitrij Riurikow wyraził się wprost, nazywając Ukrainę „tymczasowym zjawiskiem”. Prozachodnio nastawieni politycy rosyjscy od 1994 r. lansowali tezę, że „Rosja [...] powinna w przyszłości odzyskać kontrolę nad Ukrainą"66. Hipotezę tę do pewnego stopnia mogą potwierdzić słowa byłego szefa niemieckiej dyplomacji Joschki Fischera zawarte w wypowiedzi dla niemieckiego dziennika „Sueddeutsche Zeitung”. Jak zauważył, strategicznym celem Putina od początku było odzyskanie pozycji imperialnej przez Rosję. Kolejnym dążeniem po aneksji Krymu, aby osiągnąć status mocarstwa, jest Ukraina ${ }^{67}$.

Dzisiejsza Rosja, aby ponownie stać się imperium, musi się scalić wewnętrznic, czyli wzorem lat ubiegłych poszukać zewnętrznego wroga. Z retoryki Wladimira Putina wynika, że główna inspiracja dla zachowań na kijowskim Prospekcie Pobedy (lepiej znanym jako Majdan) inspirowana była przez zachodnie siły, w tym Polskę, a ich celem było obalenie legalnie istniejącego rządu i przekazanie władzy w ręce faszystów wrogo nastawionych do Rosji. W tym samym czasie szef rosyjskiej dyplomacji, potępiając świat, który uznał nowo powstały rząd w Kijowic, nawołuje do kolejnego pogwałcenia prawa międzynarodowego i wymuszenia na suwerennym pań-

64 Z. Brzeziński, Wielka szachownica, Warszawa 1998, s. 53.

65 P. Hassner, op. Cit., s. 33.

66 Z. Brzeziński, op. cit., s. 129.

$67 \mathrm{http}: / /$ wiadomosci.onet.pl/swiat/fischer-ustepstwa-wobec-putina-narazaja-na-szwank-pokoj-w-europie/cpedv [dostęp: 29.03.2014 r., godz. 15:20]. 
stwie ukraińskim zgody na federalizację ${ }^{68}$. Retoryka ta pozwala wskrzesić stare namiętności i odnajduje wroga w najbliższym otoczeniu Rosji. W ten cyniczny sposób Putin zdołał wzbudzić poparcie dla swych czynów nawet u niedawnego wroga. Prezydent Afganistanu Hamid Karzaj wraz z rządem oficjalnie uznali ancksję Krymu ${ }^{69}$.

Stanowisko Kremla w sprawach „bliskiej zagranicy” nie jest niczym nowym. W roku 1993 przewodniczący parlamentarnej komisji spraw zagranicznych Rosji J. Ambarcumow stwierdził, że: „tereny byłego Związku Sowieckiego są wyłącznie strefą wpływów geopolitycznych Rosji”. Rok później argumenty te zostały powtórzone i potwierdzone przez Andrieja Kozyriewa. Zauważył on, że: „Rosja musi zachować swoją obecność wojskową w regionach, które od stuleci stanowią obszar jej interesów". Na przełomie września i października 1995 r. prezydent B. Jelcyn tym razem w oficjalnym dokumencie przedstawił główne cele polityki Rosji, pośród których wymienił odtworzenie ,zintegrowanego gospodarczo i politycznie stowarzyszenia państw” gwarantującego Rosji „,należne miejsce na świecie” oraz „umocnienie pozycji Rosji jako wiodącej siły [...] stosunków politycznych i gospodarczych na terytorium dawnego ZSRR". W przywołanym dokumencie mowa także o konieczności zagwarantowania dostępu telewizji oraz radia a także prasy rosyjskiej na terenach dawnego Związku Sowieckiego. W kolejnych zdaniach dokument wspomina o przywiązaniu szczególnej roli do „odbudowy pozycji Rosji jako głównego ośrodka edukacyjnego na terenach” byłego „ZSRR [...] pamiętając o potrzebie wychowania młodzieży [...] w duchu przyjaźni z Rosją". Z. Brzeziński w Wielkiej szachownicy zwraca uwagę, że zarówno Krym, jak i Sewastopol, dla którego Rosja żądała eksterytorialności, stanowiły od początku rozpadu ZSRR punkt niezgody ${ }^{70}$. Cele polityki rosyjskiej wyznaczone jeszcze za administracji prezydenta B. Jelcyna i dzisiejsze posunięcia Kremla wskazują jednoznacznie na dążenie do odbudowy pozycji Rosji jako mocarstwa o charakterze euroazjatyckim. Brak wystarczających argumentów politycznych i gospodarczych mogących stanowić spoiwo dla regionu określanego mianem „bliskiej zagranicy” kolejny raz zastąpiony został siłą. Trudno

68 http://www.wprost.pl/ar/441980/Lawrow-Rosja-bedzie-nalegac-na-federalizacji-Ukrainy/ [dostęp: 29.03.2014 r., godz. 15:23].

69 http://wyborcza.pl/1,76842,15675315,Afganistan poparl aneksje Krymu Kto jeszcze uznaje.html\#ixzz2xKv878Ec [dostęp: 29.03.2014 r., godz. 13:00].

70 Z. Brzeziński, op. cit., s. 129-147. 
jednoznacznie ocenić, czy mamy już do czynienia z nową zimną wojną, faktem jednak jest, że NATO zostało postawione w stan gotowości, a tym samym zmuszone do powrotu do jego podstawowych funkcji, czyli obrony integralności państw sojuszu ${ }^{71}$.

\section{Wnioski}

Zaprezentowany powyżej materiał uprawnia do konstatacji, że dynamice rozwoju współczesnego świata towarzyszy stały wzrost zagrożeń. Źródłem powstających niebezpieczeństw dla dzisiejszej cywilizacji nie są wyłącznie dążenia państw niestabilnych do posiadania broni masowego rażenia oraz nowe mutacje terroryzmu, dla których paliwem nader często stają się różne odmiany fundamentalizmu religijnego oraz skrajnie zabarwione ideologie polityczne. Wraz z ewolucją oraz towarzyszącym jej wzrostem zapotrzebowania na energię dokonuje się stała degradacja środowiska ekologicznego współczesnego człowicka. Zjawisko to może się przyczyniać do eskalacji zagrożeń umożliwiających surowcowy lub ekonomiczny szantaż oraz próby podporządkowania silnym graczom państw słabo rozwiniętych lub ubogich w surowce energetyczne. Jako zagrożenia dla stabilności ekonomicznej oraz politycznej świata, a także człowieka jawią się spekulacje i nadużycia w dziedzinie globalnej bankowości. Wiele niebezpieczeństw wynika z zapóźnienia cywilizacyjnego oraz nadmiernej biedy rozlicznych rejonów świata. Przyczyną pogłębiających się różnic pomiędzy „bogatą Północą” a „biednym Południem”, poza konfliktami, narastającym zagrożeniem, jest exodus przedstawicieli społeczeństw dotkniętych kryzysem. Zjawiskiem sprzyjającym powstawaniu fali zagrożeń niesionej przez emigracje jest brak poszanowania dla fundamentalnych praw człowieka, odmienność kulturowa oraz odmienny system wartości. Jedną z możliwości dostrzegania powyższych wyzwań oraz redukowania skali wynikających $z$ nich zagrożeń jest właściwa analiza zmian zachodzących w środowisku zewnętrznym i wewnętrznym państwa, a także zagwarantowanie odpowiedniego poziomu edukacji w powyższym zakresie.

71 http:/wiadomosci.onet.pl/kraj/marcin-zaborowski-w-grupie-doradcow-sekretarza-generalnego-nato-granice-polski-sa/2fpmv [dostęp: 27.03.2014 r., godz. 21:10]. 
Zadaniem stojącym przed współczesnym systemem edukacji dla zagwarantowania bezpieczeństwa człowieka, społeczeństwa i państwa powinno być możliwie gruntowne zapoznanie obywateli z potencjalnymi zagrożeniami, sposobami zapobiegania niebezpieczeństwom oraz wezesnej ich neutralizacji na podstawie przesłanek oraz wyzwań. Kształcenie w tym zakresie powinno obejmować ustawiczną edukację dzieci, młodzieży oraz osób dorosłych. Celem edukacji powinno być ,intencjonalne sposobienie człowieka [...] do aktywności przez uwalnianie i doskonalenie jego podmiotowości" oraz „doskonalenie człowieka wolnego" przywiązującego na równi wagę do bezpieczeństwa swojego oraz innych osobników, używając metod pokojowych oraz metod sztuki wojennej ${ }^{72}$. Na gruncie polskim odpowiedzialnymi za edukację w zakresie bezpieczeństwa są: Urząd Rady Ministrów, Ministerstwo Obrony Narodowej, Ministerstwo Spraw Wewnętrznych, Ministerstwo Edukacji Narodowej oraz Ministerstwo Nauki i Szkolnictwa Wyższego. Główne zadania, jakie stoją przed powyżej wymienionymi instytucjami, to: zaznajamianie $z$ wiedzą $z$ zakresu bezpieczeństwa, sposobami skutecznej ochrony, wpływanie na właściwy stosunek do zadań wypływających $\mathrm{z}$ istoty bezpieczeństwa pojedynczego obywatela oraz państwa, świadome i aktywne uczestnictwo w przeciwdziałaniu i eliminacji powstałych zagrożeń.

\section{Bibliografia}

\section{Prace zwarte i publicystyka}

Balcerowicz B., Obrona państwa średniego, Warszawa 1997.

Bendyk E., Antymatrix. Człowiek w labiryncie sieci, Warszawa 2004.

Boryczka J., Stopa-Boryczka M., Kożuchowska K., Zmiany klimatu wywolane przez czlowieka, [w:] Katastrofy i zagrożenia we współczesnym świecie, Warszawa 2008.

Botkin J., Elmandjra M., Malitza M., Uczyć się bez granic. Jak zewrzeć „, lukę ludzkq", Warszawa 1982.

Brzeziński Z., Wielka szachownica, Warszawa 1998.

72 A. Pieczywok, op. cit., s. 116-145, 248. 
Flemming M., Terroryzm polityczny w międzynarodowym prawodawstwie, Wojskowy Przegląd Prawniczy 1996, nr 1.

Grabowski K., Znaczenie kultury i oświaty w procesie odzyskiwania racji stanu przez Polskę Rzeczpospolita, [w:] Zbliżenia cywilizacyjne. Edukacja, kultura, polityka, (red.) A. Sepkowski, Włocławek 2013.

Gryz J., Bezpieczeństwo państwa. Wladza-polityka - strategia, Warszawa 2013.

Hassner P., Koniec pewników, esej o wojnie, pokoju i przemocy, Warszawa 2002.

Human Security Centre, Human Security Report 2005, Oxford 2005.

Jaskicrnia J., Bezpieczeństwo państwa a ochrona praw $i$ wolności jednostki, [w:] Świat wobec wspólczesnych wyzwań i zagrożen, (red.) J. Symonides, Warszawa 2010.

Jenkins B. M., International Terrorism. A New Mode of Conflict. California Seminar on Arms Control and Foreign Policy, Los Angeles 1975.

Kaczmarski M., Problem proliferacji broni masowego rażenia, [w:] Świat wobec wspólczesnych wyzwań i zagrożeń, (red.) J. Symonides, Warszawa 2010.

Kaczmarski M., Problematyka zbrojeń i rozbrojenia, [w:] Bezpieczeństwo międzynarodowe po zimnej wojnie, (red.) R. Zięba, Warszawa 2008.

Kissinger H., Dyplomacja, Warszawa 2009.

Kitler W., Istota bezpieczeństwa narodowego, [w:] Edukacja obronna spoleczeństwa, (red.) B. Wiśniewski, W. Fehler, Białystok 2006.

Koziej S., Bezpieczeństwo: istota, podstawowe kategorie i historyczna ewolucja, Bezpieczeństwo Narodowe 2011, t. 18, nr 2.

Kozielecki J., Człowiek wielowymiarowy, Warszawa 1996.

Kozub M., Myśleć strategicznie o bezpieczeństwie przyszłości, Warszawa 2013.

Krause J., The proliferation of weapons of mass destruction: The risks for Europe, Chaillot Paper 1996, No. 5.

Kundzelewicz Z. W., Kowalczyk P., Zmiany klimatu $i$ ich skutki, Poznań 2008.

Leszczyński M., Bezpieczeństwo społeczne Polaków wobec wyzwań XXI wieku, Warszawa 2011.

Łastawski K., Racja stanu Rzeczypospolitej Polskiej, Warszawa 2000. 
Łomny Z., Człowiek i edukacja wobec przemian globalnych, Radom 1996.

Madej M., Zagrożenia asymetryczne bezpieczeństwa państw obszaru transatlantyckiego, Warszawa 2007.

Madej M., Cyberterroryści, cyberprzestepcy i hakerzy, [w:] Świat wobec wspólczesnych wyzwań i zagrożeń, (red.) J. Symonides, Warszawa 2010.

Marczak J., Spoleczeństwo w tworzeniu bezpieczeństwa narodowego, [w:] Podstawy bezpieczeństwa narodowego Polski w erze globalizacji, (red.) R. Jakubczak, Warszawa 2008,

Meadows D. H., Meadows D. L., Randers J. et al., Granice wzrostu. Pierwszy raport dla Klubu Rzymskiego, Warszawa 1973.

Mesarovic M., Pestel E., Ludzkość w punkcie zwrotnym, Warszawa 1978.

Nakonieczna J., Migracje międzynarodowe jako wyzwanie we wspólczesnym świecie, [w:] Świat wobec wspólczesnych wyzwań i zagrożen, (red.) J. Symonides, Warszawa 2010.

Nowa encyklopedia powszechna, Warszawa 1997.

Pieczywok A., Edukacja dla bezpieczeństwa wobec zagrożeń $i$ wyzwań wspótczesności, Warszawa 2012.

Pietraś Z. J., Podstawy teorii stosunków międzynarodowych, Lublin 1986.

Polska w obliczu wspólczesnych wyzwań cywilizacyjnych, Warszawa 1991.

Półturzycki J., Dydaktyka dla nauczycieli, Toruń 1997.

Pronińska K., Ewolucja zagrożeń bezpieczeństwa energetycznego, [w:] Świat wobec wspótczesnych wyzwań i zagrożeń, (red.) J. Symonides, Warszawa 2010.

Rudnicki B., Edukacja dla bezpieczeństwa i jej interpretacja, [w:] Edukacja dla bezpieczeństwa, materialy z konferencji naukowej 23-24 maja 1994, (red.) R. Stępień, Warszawa 1994.

Sienkiewicz P., 25 wykladów, Warszawa 2013.

Siuda T., Zaczek-Zaczyński K., Edukacja obronna, [w:] Współczesne zagrożenia edukacji dla bezpieczeństwa, (red.) R. Stępicń, Warszawa 1999.

Stańczyk J., Wspólczesne pojmowanie bezpieczeństwa, Warszawa 1996.

Strulak T, Niebezpieczeństwo rozprzestrzeniania broni masowego rażenia, [w:] Organizacja Narodów Zjednoczonych. Bilans i perspektywy, (red.) J. Symonides, Warszawa 2006.

Sulowski S., O nowym paradygmacie bezpieczeństwa, [w:] Bezpieczeństwo wewnętrzne państwa: wybrane zagadnienia, Warszawa 2009. 
Szymonik A., Organizacja i funkcjonowanie systemów bezpieczeństwa, Warszawa 2011.

Tinbergen J., O nowy lad międzynarodowy, Warszawa 1978.

Toffler A., Learning for Tomorrow. The Role of the Future in Education, New York 1974.

Toffler A., Trzecia fala, Warszawa 1985.

Tomasiewicz J., Terroryzm na tle przemocy politycznej. Zarys encyklopedyczny, Katowice 2000.

Williams $\mathrm{Ph}$., Transnational criminal organizations and international security, Survival 1994, No. 1.

Wyciechowska I., Przestepczość zorganizowana i przemyt ludzi, [w:] Świat wobec wspólczesnych wyzwań i zagrożeń, (red.) J. Symonides, Warszawa 2010.

Zięba R., Nowe wyzwania i zagrożenia dla bezpieczeństwa międzynarodowego: aspekt metodologiczny, [w:] Świat wobec współczesnych wyzwań i zagrożeń, (red.) J. Symonides, Warszawa 2010.

Zięba R., Pojęcia i istota bezpieczeństwa międzynarodowego, [w:] Bezpieczeństwo międzynarodowe po zimnej wojnie, (red.) R. Zięba, Warszawa 2008.

Zięba R., Teoria ogólna bezpieczeństwa w stosunkach międzynarodowych, [w:] Stosunki międzynarodowe w XXI wieku, (red.) E. Haliżak, Warszawa 2006.

\section{Źródla internetowe:}

http://pl.wikipedia.org/wiki/Zamachy_w_Norwegii_\%282011\%29 [dostęp: 3.01.2014 r.).

http://polish.ruvr.ru/2013_12_31/Spolecznosc-miedzynarodowa-jest-wstrzasnieta-zamachami-wWolgogradzie [dostęp: 3.01.2014 r.].

http://wiadomosci.onet.pl/kraj/marcin-zaborowski-w-grupie-doradcow-sekretarza-generalnego-nato-granice-polski-sa/2 fpmv [dostęp: 27.03.2014, godz. 21:10].

http://wiadomosci.onet.pl/swiat/byly-premier-libii-ostrzega-zachod/cx8qg [dostęp: 27.03.2014 r. godz. 15:49].

http://wiadomosci.onet.pl/swiat/fischer-ustepstwa-wobec-putina-narazaja-na-szwank-pokoj-w-europie/cpedv [dostęp: 29.03.2014, godz. 15:20]. 
http://www.wprost.pl/ar/441980/Lawrow-Rosja-bedzie-nalegac-na-federalizacji-Ukrainy/ [dostęp: 29.03.2014 r. godz. 15:23].

http:/wyborcza.pl/1,76842,15675315,Afganistan_poparl_aneksje_Krymu_Kto_jeszcze_uznaje.html\#ixzz2xKv878Ec [dostęp: 29.03.2014, $\operatorname{godz.} 13: 00]$. 